Fukushima J. Med. Sci.,

Vol. 48, No.2, 2002

[Regular Papers]

\title{
ANTIKERATIN ANTIBODIES IN SERA OF PATIENTS WITH CONNECTIVE TISSUE DISEASE AND LIVER DISEASE
}

\author{
ISAO TAKEDA ${ }^{1)}$, HARUYO IWADATE ${ }^{1)}$, KOTA SUGISAKI'), \\ TAKASHI KANNO ${ }^{1)}$, JOTARO SHINZAWA ${ }^{2)}$ and REIJI KASUKAWA ${ }^{1)}$ \\ ${ }^{1)}$ Divisions of Rheumatology and ${ }^{2)}$ Digestive Organ Disease, Ohta Nishinouchi Hospital, Koriyama
} (Received April 30, 2002, accepted May 27, 2002)

\begin{abstract}
Sera from 93 patients with connective tissue disease, 36 rheumatoid arthritis, 41 systemic lupus erythematosus, 12 polymyositis/dermatomyositis and 4 systemic sclerosis and sera from 12 patients with liver disease, along with sera of 10 healthy subjects, were tested for antikeratin antibodies using enzyme-linked immunosorbent assay in which the wells were coated with human epidermal keratin.

Values above the mean $+\mathrm{SD}$ of the 10 healthy subjects were found in $8.3 \%$ of rheumatoid arthritis, $29.3 \%$ of systemic lupus erythematosus, $33.3 \%$ of polymyositis/ dermatomyositis, $50 \%$ of systemic sclerosis, $16.7 \%$ of liver disease patients, and $20 \%$ of healthy subjects. The results indicated a character of naturally occurring antibody of antikeratin antibodies in human sera.
\end{abstract}

Key words : keratin antibody, natural antibody, ELISA, connective tissue disease, liver disease

\section{INTRODUCTION}

Antikeratin antibodies have been reported as one of the specific antibodies for rheumatoid arthritis (RA) since the first report by Young et al. ${ }^{1)}$ in 1978.

Due to the difficulty in solubilizing keratin, cytoplasmic intermediate filaments of epidermis, antikeratin antibodies were previously detected by indirect immunofluorescence using the rat oesophageal epithelium ${ }^{2,3,4}$. Recently available soluble ketatin antigen induced a detection of antikeratin antibodies by enzymelinked immunosorbent assay (ELISA) ${ }^{5,6,7)}$.

The target antigen for the antikeratin antibodies in RA patients was recently characterized as filaggrin and anti-filaggrin antibodies were studied by ELISA ${ }^{8,9)}$ and immunoblotting ${ }^{9,10)}$. In the present study, the presence of antikeratin antibodies in the sera of patients with connective tissue disease and liver disease were determined

武田 功，岩舘治代，杉崎康太，菅野 孝，新澤穣太郎，粕川禮司

Reprint requests to: Reiji Kasukawa, Institute of Rheumatic Diseases, Ohta General Hospital

Foundation, Koriyama City 963-8004, Japan. 
through ELISA using human epidermal keratin.

\section{MATERIALS AND METHODS}

Patients: A total 105 patients; 36 with rheumatoid arthritis (RA), 41 with systemic lupus erythematosus (SLE), 12 with polymyositis/dermatomyositis (PM/ $\mathrm{DM}$ ), 4 with systemic sclerosis (SSc) and 12 with liver disease (4 with chronic hepatitis B, 3 with chronic hepatitis C, 3 with drug-induced hepatitis and 2 with autoimmune hepatitis) was included in the present study. All patients were admitted to or attending Rheumatology or Digestive Organ Disease Units of Ohta Nishinouchi Hospital. Diagnosis of connective tissue disease was performed using the 1987 ARA revised criteria for RA ${ }^{11)}$, the 1997 ACR criteria for SLE ${ }^{12)}$, the 1975 Bohan's criteria for PM/DM ${ }^{13)}$ and the ACR criteria for $\mathrm{SSc}^{14)}$. Diagnosis of liver disease was performed by taking anamnesis, conducting liver function test, including tests for hepatitis $\mathrm{B}$ and $\mathrm{C}$ virus and, histological examination of biopsied liver specimens for autoimmune hepatitis.

Sera: The sera were separated from the clotted venous blood. The sera were kept at $-20^{\circ} \mathrm{C}$ until used. Before testing the sera, sera were heated at $56^{\circ} \mathrm{C}$ for 30 min.

ELISA: The antikeratin antibody was detected using ELISA following the method described by Aoki et al. ${ }^{6}$. Briefly, Costa U-bottomed microtiter plates (Corning, Corning, NY) were filled with $100 \mu \mathrm{l}$ of $100 \mu \mathrm{g} / \mathrm{ml}$ human dermal keratin (Sigma, St. Louis, MO) dissolved in a solution of $8 \mathrm{M}$ urea, $0.1 \mathrm{M}$ Tris- $\mathrm{HCl}, \mathrm{PH}$ 9.0, $50 \mathrm{mM} 2 \mathrm{ME}$ and diluted with a coating solution $\left(0.05 \mathrm{M} \mathrm{Na}_{2} \mathrm{CO}_{3}, 0.035 \mathrm{M} \mathrm{NaHCO}_{3}\right.$, $0.02 \% \mathrm{NaN}_{3}, \mathrm{PH}$ 9.6). The plates were incubated at room temperature for 2 hours. The coating solution was discarded and the plates were washed 3 times for $5 \mathrm{~min}$ each, using phosphate buffered saline (PBS) containing 0.05\% Tween-20 (PBSTween). The plates were filled with $200 \mu 1$ of $1 \%$ bovine serum albumin (BSA) solution in PBS (1\% BSA-PBS) and incubated at $4^{\circ} \mathrm{C}$ over night. The $1 \% \mathrm{BSA}-$ PBS was discarded, the plates were washed 3 times and then were filled with $100 \mu 1$ of $1: 100$-diluted serum samples in $1 \%$ BSA-PBS. The plates were incubated at room temperature for 2 hours. After washing 3 times, the plates were filled with 100 $\mu 1$ of alkaline-phosphatase (AP)-conjugated goat anti-human gamma chain specific IgG serum (Sigma) diluted at 1:3000 with 1\% BSA-PBS, and incubated at room temperature for one and a half hours. The plates were washed 3 times with PBSTween and the enzyme reaction was performed with $100 \mu 1$ of the substrate solution of para-nitrophenyl phosphate disodium (Sigma) at room temperature for 40 minutes and absorbance were read at $450 \mathrm{~nm}$ using multiscan photometer.

Standard curve: In the antikeratin ELISA test, the wells were filled with $100 \mu 1$ of $1: 600,1: 1200,1: 2400,1: 4800,1: 9600$-diluted guinea pig IgG anti-human epidermal keratin serum in 1\% BSA-PBS. The plates were incubated at room temperature for 2 hours. After washing 3 times, the plates were filled with $100 \mu$ l of AP- 
conjugated rabbit anti-guinea pig IgG serum (Sigma) diluted $1: 3000$ with 1\% BSAPBS and incubated at room temperature for one and a half hours. After washing 3 times with PBS-Tween, the enzyme reaction with the substrate solution was performed and absorbance was read at $450 \mathrm{~nm}$ in the same way as for the test samples. Optical density (OD) values for the five dilutions of guinea pig antikeratin serum were plotted using the semi-logarithmic scale and a line of best fit was drawn. The OD value of $1: 600$-diluted guinea pig antikeratin serum was given an arbitrary value of 100 units $/ \mathrm{ml}$ for antikeratin antibodies.

Inhibition test for guinea-pig antikeratin antibodies: The reaction mixture consisted of an equal volume of 1 : 300-diluted guinea pig IgG anti-human epidermal keratin serum and of $250 \mu \mathrm{g} / \mathrm{ml}, 125 \mu \mathrm{g} / \mathrm{ml}, 62.5 \mu \mathrm{g} / \mathrm{ml}, 31.3 \mu \mathrm{g} / \mathrm{ml}$ or $0 \mu \mathrm{g} / \mathrm{ml}$ of keratin solution was incubated in the separate tubes for one hour at room temperature. The wells of the antikeratin ELISA test were filled with $100 \mu 1$ each of the reaction mixture. The plates were incubated at room temperature for 2 hours. After washing 3 times, the wells were filled with $100 \mu 1$ of AP-conjugated rabbit anti-guinea pig IgG serum and absorbance was read at $450 \mathrm{~nm}$ in the same way as for the ELISA test.

Inhibition test for human anti-keratin antibodies: The reaction mixture consists of equal volume of $1: 50$ diluted positive human serum and of $200 \mu \mathrm{g} / \mathrm{ml}$ of keratin was incubated in the separate tubes for one hour at room temperature. The wells of the antikeratin ELISA test were filled with $100 \mu 1$ each of the reaction mixture. The plates were incubated at room temperature for 2 hours. After washing 3 times, the wells were filled with $100 \mu 1$ of AP-conjugated goat anti-human gamma chain specific IgG serum and the absorbance was read at $450 \mathrm{~nm}$ in the same way as for the ELISA test.

\section{RESULTS}

The detection method for anti-human dermal keratin antibody was established in ELISA test. A standard curve obtained by the reaction between five dilutions of guinea pig antikeratin antibodies, $1: 600,1: 1200,1: 2400,1: 4800$ and $1: 9600$, and human dermal keratin on the ELISA plates was evaluated to be useful for estimating the values of antikeratin antibodies ranging from 15 to $100 \mathrm{u} / \mathrm{ml}$ (Fig. 1). In addition, the inhibition test for guinea pig antikeratin antibody by keratin was evaluated to be specific for keratin (Fig 2).

The results of the ELISA test for anti-keratin antibodies in sera of patients with connective tissue disease and liver disease, along with sera of healthy subjects were presented in Fig 3. The mean $\pm \mathrm{SD}$ values of antikeratin antibodies for patients with connective tissue disease and liver disease including healthy subjects were very close in the following range from $23.8 \pm 15.2 \mathrm{u} / \mathrm{ml}$ of RA to $31.0 \pm 9.0 \mathrm{u} / \mathrm{ml}$ of SSc, indicating no significant difference in mean values among them. Positive reaction, values above the mean $+\mathrm{SD}$ of healthy subject, was found in 3 of 36 (8.3\%) RA, 12 


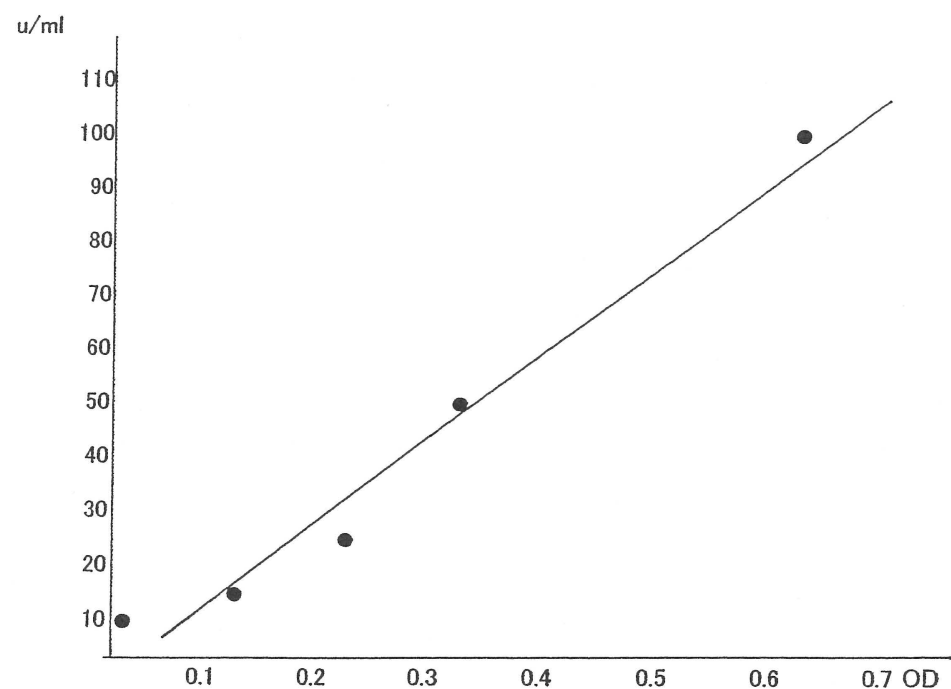

Fig. 1. Standard curve for antikeratin antibodies in ELISA. Five optical density (OD) values of guinea pig antikeratin serum diluted at $1: 600,1: 1200,1: 2400,1$ : 4800 and 1:9600 in ELISA were plotted on semi-logarithmic scale. After curve fitting, 1:600-diluted guinea pig antikeratin serum was assigned to arbitrary value of 100 units/ml for antikeratin antibodies.

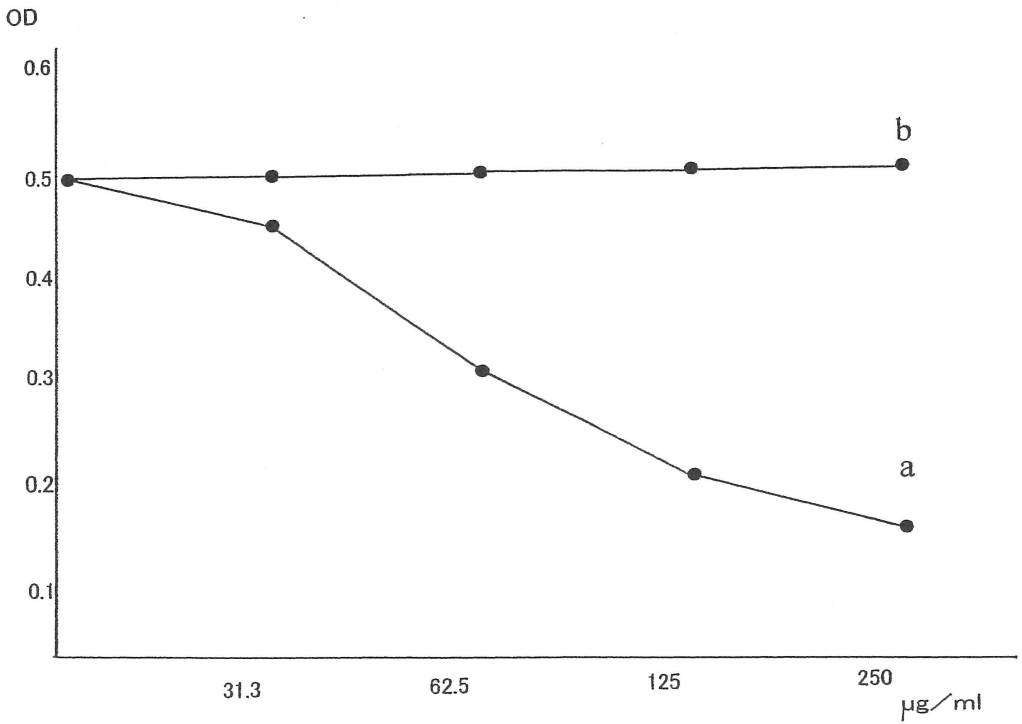

Fig. 2. Inhibition test for guinea pig antikeratin antibodies. One hundred $\mu 1$ of 1 : 300-diluted guinea pig antikeratin antibody was mixed with $100 \mu 1$ each of 250 $\mu \mathrm{g} / \mathrm{ml}, 125 \mu \mathrm{g} / \mathrm{ml}, 62.5 \mu \mathrm{g} / \mathrm{ml}, 31.3 \mu \mathrm{g} / \mathrm{ml}$ or $0 \mu \mathrm{g} / \mathrm{ml}$ of keratin and mixture was tested by ELISA. Five OD values were plotted in graph (a). OD values of the 1:300-diluted antikeratin antibody mixed with 1\% BSA-PBS alone are plotted as controls (b). 


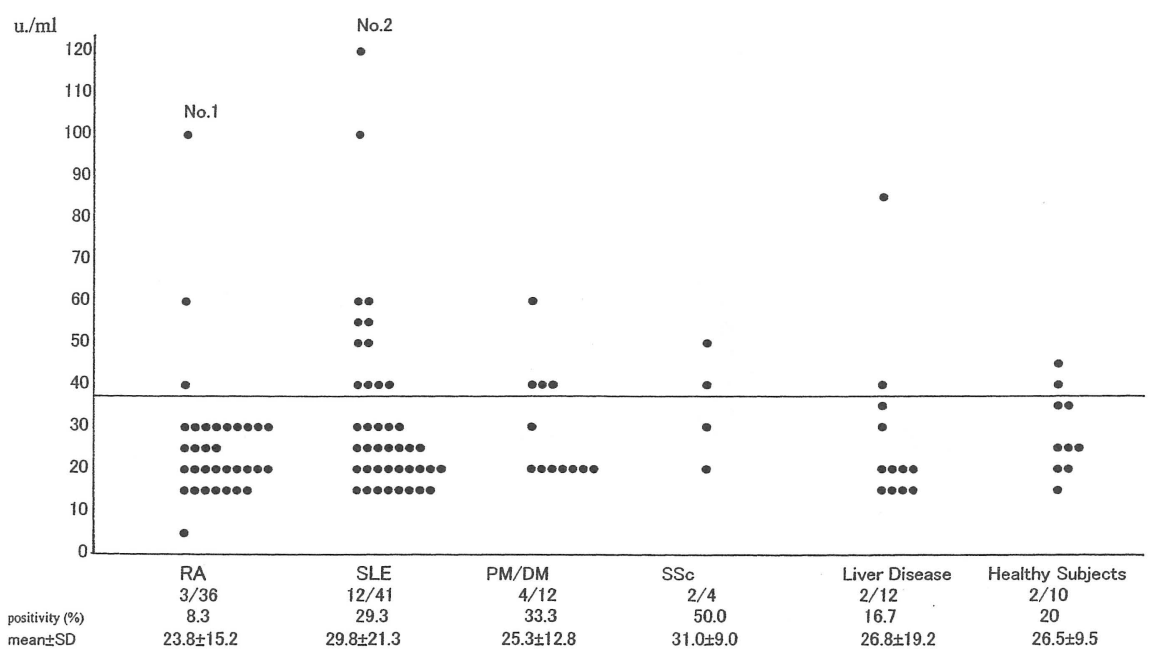

Fig. 3. ELISA for antikeratin antibodies in sera of patients with connective tissue disease and liver disease, and in sera of healthy subjects. A solid line indicates mean $+\mathrm{SD}$ value of sera of 10 healthy subjects.

RA, rheumatoid arthritis; SLE, systemic lupus erythematosus; PM/DM, polymyositis/dermatomyositis; SSc, systemic sclerosis.

of $41(29.3 \%)$ SLE, 4 of 12 (33.3\%) PM/DM, 2 of 4 (50\%) SSc and 2 of 12 (16.7\%) liver disease patients. However, 2 of 10 (20\%) healthy subjects also demonstrated the levels above the mean+SD (Fig 3). Elevated levels of antikeratin antibodies were not confined to the patients with specific disease.

Higher titers for antikeratin antibodies obtained from one of RA sera (No. 1 in Fig 3) and one of SLE sera (No. 2 in Fig 3) were found to be inhibited by keratin in mixing $100 \mu \mathrm{l}$ of $1: 50$-diluted serum with $100 \mu \mathrm{l}$ of $200 \mu \mathrm{g} / \mathrm{ml}$ of keratin in the ELISA test; a shift of values from $98 \mathrm{u} / \mathrm{ml}$ to $16 \mathrm{u} / \mathrm{ml}$ in No. 1 RA serum and from $118 \mathrm{u} / \mathrm{ml}$ to $20 \mathrm{u} / \mathrm{ml}$ in No. 2 SLE serum. In the clinical course of No. 1 RA patient, the levels of antikeratin antibodies correlated roughly with the levels of C-reactive protein and erythrocyte sedimentation rate (Fig 4a). In contrast, in the clinical course of No. 2 SLE patient, the levels of antikeratin antibodies did not correlate with the levels of hemolytic complement activity (CH50) or the levels of anti-DNA antibodies (Fig 4b).

\section{DISCUSSION}

Antikeratin antibodies have been detected mainly by indirect immunofluorescence using the rat oesophageal epithelium. ELISA has recently become available for detection of antikeratin antibodies. In the present study, we applied ELISA for the detection of antikeratin antibodies in sera from patients with connective tissue disease and liver disease using crude keratin antigen originated 

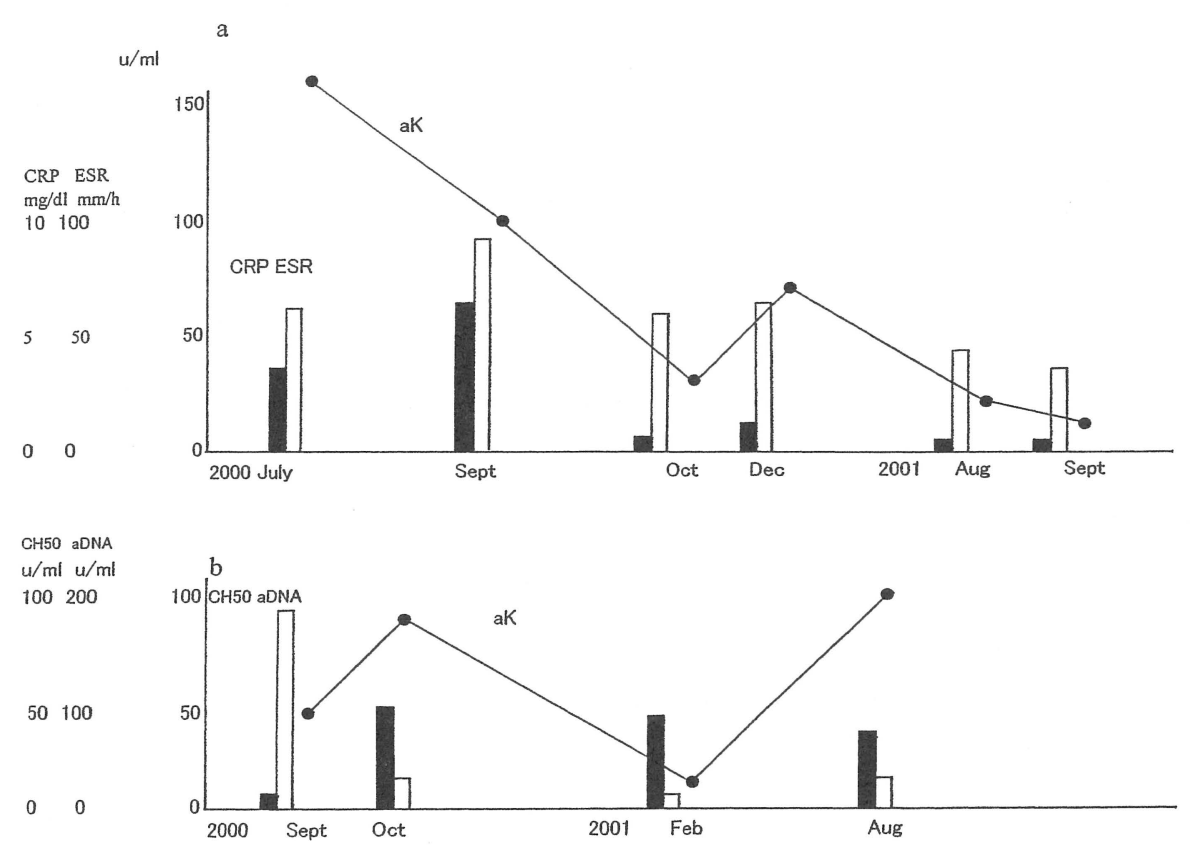

Fig. 4. ELISA values for antikeratin antibodies and values of laboratory tests in RA patient (No. 1) (a) and SLE patient (No.2) (b) during their clinical courses. CRP, C-reactive protein ; ESR, erythrocyte sedimentation rate ; CH50, hemolytic complement activity; aDNA, anti-DNA antibody; aK, antikeratin antibodies.

from human dermis.

Elevated levels of antikeratin antibodies in sera of patients with rheumatoid arthritis were reported by many investigators ${ }^{2,3,4,8,15,16,17,18,19,20)}$. However, in the present study, we could not confirm such results of antikeratin antibodies in rheumatoid arthritis patients. Instead, antikeratin antibodies were found with similar frequency and titers in the sera of patients with RA, SLE, PM/DM, SSc, liver disease and also in the sera of healthy subjects. Therefore, the antikeratin antibodies found in the present study are likely to be naturally occurring antibodies present ubiquitously in human sera, as was suggested by Iwatsuki et al. ${ }^{5}$. The purity of keratin antigen and/or type of keratin used in ELISA may explain some of the differences between the results reported by other investigators and those obtained in the present study. Recent analysis has shown that there are more than 20 types of keratin antigen ${ }^{21}$.

The epidermal keratin used in the present study was reported to contain types 5, 6, 15 and 16 keratin $^{21)}$. The types 15 and 16 keratin are also present in esophageal epithelium ${ }^{21}$. Antikeratin antibodies have been detected in the sera of patients with autoimmune chronic active hepatitis. These antibodies were characterized as antisoluble liver antigen antibodies ${ }^{22)}$. The target antigen of antikeratin antibodies in liver disease was characterized as types 8 and 18 keratin ${ }^{22}$. Therefore, the specificity of antikeratin antibodies for keratin antigens associated with either 
connective tissue disease or chronic liver disease should be studied, using the specific types of keratin antigens.

In conclusion, an ELISA for antikeratin antibodies to human epidermal keratin was established. Antikeratin antibodies detected in sera of patients with connective tissue disease and liver disease had the character of naturally occurring antibodies.

\section{REFERENCES}

1. Young BJJ, Mallya RK, Leslie RDG, Clark CJM, Amblin TJ, Antikeratin antibodies in rheumatoid arthritis. Br Med J, 2, 97-99, 1978.

2. Mallya RK, Young BJJ, Pepys MB, Hamblin TJ, Mace BEW, Hamilton EBD, Antikeratin antibodies in rheumatoid arthritis: frequency and correlation with other features of the disease. Clin Exp Immunol, 51, 17-20, 1983.

3. Vincent C, Serre G, Basile J-P, Lestra HC, Girbal E, Sebbag M, Soleihavoup JP, Subclass distribution of IgG antibodies to the rat oesophagus stratum corneum (so-called antikeratin antibodies) in rheumatoid arthritis. Clin Exp Immunol, 81, 83-89, 1990.

4. Kessel A, Rosner I, Zuckermann E, Golan TD, Toubi E, Use of antikeratin antibodies to distinguish between rheumatoid arthritis and polyarhritis associated with hepatitis $\mathrm{C}$ infection. J Rheumatol, 27, 610-612, 2000.

5. Iwatsuki K, Viac K, Reano A, Morera A, Staquet M-J, Thivolet J, Monier JC, Comparative studies on naturally occurring antikeratin antibodies in human sera. J Invest Dermatol, 87, 179-184, 1986.

6. Aoki S, Yaoita H, Kikajima Y, An elevated level of autoantibodies against 48 - to $50 \mathrm{kd}$ keratin in the serum of patients with psoriasis. J Invest Dermatol, 92, 179-183, 1989.

7. Aho K, von Essen R, Kurki P, Palosuo T, Helioevaara M, Antikeratin antibody and antiperinuclear factor as markers for subclinical rheumatoid disease process. J Rheumatol, 20, 1278-1281, 1993.

8. Aho $\mathrm{K}$, Palosuo $\mathrm{T}$, Lukka M, Kurki $\mathrm{P}$, Isomaeki $\mathrm{H}$, Kautiainen $\mathrm{H}$, von Essen $\mathrm{R}$, Antifilaggrin antibodies in recent-onset arthritis. Scand J Rheumatol, 28, 113-116, 1999.

9. Masson-Bassiere C, Sebbag M, Durieux JJ, Nogueira L, Vincent C, Girbal-Neuhauser E, In the rheumatoid pannus, anti-filaggrin autoantibodies are produced by local plasma cells and constitute a higher proportion of IgG than in synovial fluid and serum. Clin Exp Immunol, 51, 743-746, 1992.

10. Vincent C, Simon M, Sebbag M, Girbal-Neuhauser E, Durieux J-J, Cantagrel A, Fournie B, Mazicres B, Serre G, Immunoblotting detection of autoantibodies to human epidermis filaggrin: A new diagnostic test for rheumatoid arthritis. J Rheumatol, 25, 838-846, 1998.

11. Arnett FC, Edworthy SM, Bloch DA, McShane DJ, Fries JF, Cooper NS, Healey LA, Kaplan SR, Liang MH, Luthra HS, Medsger TA, Mitchell DM, Neustadt DH, Pinals RS, Schaller JG, Sharp JT, Wilder RL, Hunder GG, The American Rheumatism Association 1987 revised criteria for the classification of rheumatoid arthritis. Arthritis Rheum, 31, 315-324, 1988.

12. Hochberg MC, Updating the American College of Rheumatology revised criteria for the classification of systemic lupus erythematosus. Arthritis Rheum, 40, 1725, 1997.

13. Bohan A, Peter JB, Polymyositis and dermatomyositis (first of two parts). N Engl J Med, 292, 344-347, 1975.

14. Subcommittee for scleroderma criteria of the American Rheumatism Association Diagnostic and Therapeutic Criteria Committee : preliminary criteria for the classification of systemic sclerosis (scleroderma). Arthritis Rheum, 23, 581-590, 1980.

15. Paimela L, Gripenberg M, Kurki P, Leirisalo-Repo M, Antikeratin antibodies: diagnos- 
tic and prognostic markers for early rheumatoid arthritis. Ann Rheum Dis, 51, 743-746, 1992.

16. Simon M, Girbal E, Sebbag M, Gomes-Daudrix V, Vincent C, Salama G, Serre G, The cytokeratin filament-aggregating protein filaggrin is the target of the so-called "antikeratin antibodies", autoantibodies specific for rheumatoid arthritis. J Clin Invest, 92, 13871393, 1993.

17. Sebbag M, Simon M, Vincent C, Masson-Bessiere C, Girbal E, Durieux JJ, Serre G, The antinuclear factor and the so-called antikeratin antibodies are the same rheumatoid arthritis specific autoantibodies. J Clin Invest, 95, 2672-2679, 1995.

18. Berthelot J-M, Maugars Y, Castagne A, Audrain M, Prost A, Antiperinuclear factors are present in polyarthritis before ACR criteria for rheumatoid arthritis are fulfilled. Ann Rheum Dis, 56, 123-125, 1997.

19. Palosuo T, Lukka M, Alenius H, Kalkkinen N, Aho K, Kurki P, Heikkilae R, Nykaeren M, von Essen R, Purification of filaggrin from human epidermal and measurement of antifilaggrin autoantibodies in sera from patients with rheumatoid arthritis by an enzyme-linked immunosorbent assay. Int Arch Allergy Immunol, 115, 294-302, 1998.

20. Slack SL, Mannik M, Dale BA, Diagnostic value of antibodies to filaggrin in rheumatoid arthritis. J Rheumatol, 25, 847-851, 1998.

21. Lowthert LA, Ku N-O, Liao J, Coulombe PA, Omary MB, Empigen BB, A useful detergent for solubilization and biochemical analysis of keratins. Biochem Biophys Res Commun, 206, 370-379, 1995.

22. Waechter B, Kyriatsoulis A, Lohse AW, Gerken G, Meyer zum Bueschenfelde K-H, Manns M, Characterization of liver cytokeratin as a major target antigen of anti-SLA antibodies. J Hepatol, 11, 232-239, 1990. 